\title{
Fusarium oxysporum f. sp. lycopersici: How can we Control this Fungus?
}

\author{
Arturo Landeros de la Isla and Karla Lizbeth Macías-Sánchez* \\ Instituto Politécnico Nacional, México
}

Submission: June 14, 2017; Published: July 24, 2017

*Corresponding author: Karla Lizbeth Macías-Sánchez, Instituto Politécnico Nacional, UPIIG, Av Mineral de Valenciana 200, Fraccionamiento Industrial Puerto Interior, C.P. 36275, Silao de la Victoria, Guanajuato, México, Tel: +525557296000 ext.: 81380 ; Fax: +525557296000 ext.: 81450; Email: kmaciass@ipn.mx

\begin{abstract}
Fusarium oxysporum f. sp. Lycopersici is a phytopathogenic fungus of great economic importance, causing the disease known as fusariosis in the tomato plant. One of the characteristic and initial symptoms of the disease is the yellowing in various areas of the plant; later, the general wilt and finally death of the plant. Several strategies are used to combat the disease caused by this fungus, from chemical methods such as the use of fungicides from the family of benzimidazoles and triazoles as well as biological methods, involving the use of microorganisms such as Pseudomonas, Trichoderma, among others. For this reason, the continued study of this fungus is important to know how it can be controlled.
\end{abstract}

Keywords: Fusarium oxysporum; Fusariosis; Tomato

\section{Introduction}

The tomato is one of the vegetables of greater consumption and economic value in the world. Its demand increases continuously as well its cultivation, production and commerce. According to Food and Agriculture Organization of the United Nations (FAO) in 2013, China was the main tomato producer, with a production of 50 million tonnes [1]. Among the diseases of the tomato that affect the root, the fusariosis, caused by the fungus Fusarium oxysporum f. sp. lycopersici, producing production losses between 30 and $40 \%$, and may even reach up to $80 \%$, if climatic conditions favor the growth of the fungus [2]. This disease is present in a large number of countries, including North America (Canada, Mexico, USA), Central America and the Caribbean (Cuba, Panama, Jamaica) and South America (Argentina, Venezuela and Brazil), also in European countries such as France, Italy and Germany, among others [3]. The symptoms of fusariosis begin with a foliar chlorosis in a region of the plant and as the disease is established, the yellowing is observed in the majority of the plant, causing the wilt and later the death of the plant, without producing fruit or the fruit production is scarce [4].

\section{Methods of control}

Control of diseases in tomato cultivation through the use of pesticides (fungicides and soil fumigants) has helped maintain high yields and satisfy food quality. Some of the commercial chemical fungicides used with higher inhibition rates to eradicate the spread of the microorganism F. oxysporum f. sp. lycopersici in tomato crops are: prochloraz, propiconazole, thiabendazole, carbendazim, benomyl, thiophanate and fuberidazole, which belong to the benzimidazole family and are categorized as systematic fungicides [5]. Myclobutanil, triadimefon, difenoconazole, tebuconazole, epoxiconazole, belonging to the family of triazoles and categorized also as systematic fungicides, among other types of fungicides such as methoxyacrylates and ethyl phosphonates [6].

A non-chemical control method of fusariosis is to submit to treatment of humid solarizationto the soil that will be used in the seedlings for 30 to 45 days. Also, an adequate control of $F$. oxysporum is possible with the sowing of tomato seeds that have been pregerminated in suspensions of the fungus Trichoderma koningii, with applications of the same fungus and of Pseudomonas fluorescens (carried out later) on the soil of the seedlings. The preinoculation of tomato plants with Penicilliumoxalicum reduces the severity of the disease; also, the application in the seeds of the bacteria Serratiaplymuthica and Pseudomonas sp. causes a decrease in the establishment of fusariosis due to F. oxysporum. Another useful method for controlling fusariosis, in addition to those mentioned above, is the immersion of tomato roots during a period of approximately 10 minutes in a solution of marigold $10 \%$ [7]. 


\section{Conclusion}

Vascular fusariosis in the tomato plant caused by the fungus F. oxysporum f. sp. lycopersici, is one of the diseases that most affect this crop nowadays. The use of biological methods as well as the development of compounds that inhibit their growth are the methods used for the control of this disease; however, it is necessary to continue with the search for new strategies for its control.

\section{Acknowledgement}

We thank the collaboration of Paulina Serrano Sandoval for the development of Fusarium projects in the lab.

\section{References}

1. http://www.fao.org/faostat/en/\#rankings/countries_by_commodity.

2. Nirmaladevi D, Venkataramana M, Srivastava R, Uppalapati S, Gupta $\mathrm{V}$, et al. (2016) Molecular phylogeny, pathogenicity and toxigenicity of Fusarium oxysporum f. sp. lycopersici. Scientific reports 6:21367. DOI: $10.1038 /$ srep21367.
3. http://www.cabi.org/isc/datasheet/24660.

4. Báez-Valdez E, Carrillo-Fasio J, Báez-Sañudo M, García-Estrada R, Valdez-Torres J, et al. (2010) Resistant rootstocks utilization for Fusarium control (Fusarium oxysporumf. sp. lycopersici Snyder \& Hansen race 3) in tomato (Lycopersiconesculentum Mill) under shade conditions. Revista Mexicana de Fitopatología 28(2): 111-123.

5. Bawa I (2016) Management strategies of Fusarium wilt disease of tomato incited by disease of tomato incited by Fusarium oxysporum f. sp. lycopersici (Sacc.): A Review. International Journal of Advanced Academic Research 2(5): 32-42.

6. Khan A, Dliferoze A, Malik Zia-Ullah, Shoaib A, Khurshid S (2012) In vitro chemical control of Fusarium oxysporum f. sp. lycopersici. Mycopath 10(2): 57-61.

7. Jaramillo J, Rodíguez V, Guzmán M, Zapata M, Rengifo T (2007) Manual Técnico: Buenasprácticasagrícolas (BPA) en la producción de tomatebajocondicionesprotegidas. In: Jaramillo J, Rodíguez V, Guzmán M, Zapata M, Rengifo T (Eds.), FAO, Gobernación de Antioquia. (1 ${ }^{\text {st }}$ edn), MANA, CORPOICA, Centro de Investigación "La Selva”, Medellín, Colombia, pp. 1-295.

\section{Your next submission with Juniper Publishers will reach you the below assets}

- Quality Editorial service

- Swift Peer Review

- Reprints availability

- E-prints Service

- Manuscript Podcast for convenient understanding

- Global attainment for your research

- Manuscript accessibility in different formats

( Pdf, E-pub, Full Text, Audio)

- Unceasing customer service

Track the below URL for one-step submission

https://juniperpublishers.com/online-submission.php 